\title{
A Convergence of Filipino Worlds: An Onomastic Reading of Edgar Calabia Samar's Janus Silang Novels
}

\author{
Maria Rhodora G. Ancheta
}

University of the Philippines-Diliman, Quezon City, the Philippines

\begin{abstract}
Edgar Calabia Samar's Janus Silang book series is a significant body of contemporary young adult fantasy novels in the Philippines. Samar's ambitious series that successfully melds alternate online tech-worlds, everyday Filipino life, and ancient supernatural, god-inhabited worlds, is worthy of study. In creating this fantasy world, the Janus Silang series underscores the richness of Filipino mythology and lore by cohesively layering these lived worlds by way of spatial and temporal play. This paper wishes to study the value of this "world(s)-building", entering this by way of the study of onomastics, the study of proper names of all kinds and the origins of names. Using both toponomastics and anthroponomastics, or the study of place names and human naming, respectively, this inventive, powerful focus on naming solidifies the Janus Silang series' development of unique Filipino characters and narratives and its reintroduction of the cultures of its imaginary worlds for young, contemporary Filipino and global readers.
\end{abstract}

Keywords: Janus Silang, Filipino mythology, literary onomastics, anthroponyms, toponyms

Edgar Calabia Samar's Janus Silang book series is a significant body of contemporary young adult fantasy novels in the Philippines. Samar's ambitious series that successfully melds alternate online tech-worlds, everyday Filipino life, and ancient supernatural, god-inhabited worlds, is worthy of study, not only because of its awardwinning stature as a contemporary Filipino fantasy series (2015 National Book Award winner as Best Novel in a Philippine Language, 2016 National Children's Book Award, Best Read for Kids, and 2018 National Children's Book Awards), but more importantly, in creating this fantasy world, the Janus Silang series has underscored the richness of Filipino my thology and lore by cohesively layering these lived worlds by way of spatial and temporal play.

Despite the many recognitions given by prestigious award-giving bodies and the critical impact the books have made in the Young Adult (YA) literature genre in the Philippines, there has not been a lot of study done on the Janus Silang series, except for the odd book reviews and features on the series author. Expectedly, the reception of Samar's fantasy series has likened this to the "Harry Potter world" (Cayabyab), or to "Rick Riordan's 
Percy Jackson series" (de Vera). While Samar is not displeased by the comparison to these Western mega-fantasy novel series, he does say that his novels desire to transcend these comparisons, because what he really meant for these to do is to "[reflect] the rich culture of our country's folklore", to use "Philippine mythology and serialized comics", "to insert technology and social media in the narrative of Philippine mythology to hook readers to be interested in our own folklore" (Cayabyab).

As Ruel de Vera put it, the Janus Silang series, "more than just modernizing a Filipino myth [...] is an attempt to build a new one - a Filipino young adult (YA) franchise that merges "magic with modernity". The publishers of the Janus Silang series pointed to the target audience of these "to be tweens and teens, 13 years and up, and the franchise has grown beyond the novels, to a graphic novel version, play adaptations, and, in 2018, television rights to a Janus Silang series were acquired by ABS-CBN" (https://news.abscbn.com/life/09/03/18/abs-cbn-obtains-tv-rights- to-janus-silang-series).

In the light of this conscious deployment of Philippine folkloric knowledge in narrativizing the adventures of "a young Filipino hero with that most modern of interests - online role-playing games (RPGs)" (de Vera https://lifestyle.inquirer.net/158736/modernizing-a-mythical-monster/), and in anticipating the impact this will have on the youth as primary target readers of this series, and more extensively, the influence this has on fantasy as a genre in Philippine writing, I wish to study this world(s)-building, entering this by way of the study of onomastics, the study of proper names of all kinds and the origins of names. Using literary onomastics, especially as this is applied to fantasy writing, and employing both toponomastics and anthroponomastics, or the study of place names and human naming, respectively, this paper posits that this inventive, powerful focus on naming solidifies the Janus Silang series' contribution to the Filipino fantasy genre and to the presentation of Filipino worlds and the strengthening of the value of Filipino culture, not only as it de velops unique Filipino characters and narratives, but as it reintroduces the cultures of its imaginary worlds for young, contemporary Filipino and global readers.

The Janus Silang series now has four published novels — Si Janus Silangatang Tiyanakng Tabon(2014), Si Janus Silang at ang Labanang Manananggal-Mambababarang (2015), Si Janus Silang at ang Pitumpu't Pitong Pusong (2017), and Si Janus Silang at ang Hiwagang May Dalawang Mukha (2019). This discussion will mainly use the first three novels as it is in these that the creation of secondary worlds in this series is established and introduced. 


\section{Onomastics}

Lazslo Toth asserted the importance of proper names in human languages as these are related to fields of human endeavor such as history, culture, religion, the arts, among many others (2). Names used in texts are possibly its common literary characteristic as these are seen in various texts employing diverse styles and structures, functioning as key medium of reference. Names operate as primary identifiers of places, persons, or objects and as such function as onyms, the forms of which are provided by particular references to places, beings, or categories (Butler 11). Names in this general classification are proper names, of which there are two main divisions: toponyms, which are place names, and anthroponyms, which refer to personal names. There are other subdivisions of names, such as ethnonyms, which are terms that refer to nationalities or ethnic groups, and glottonyms, which refers to languages (Bright 671).

Onomastics, or onomatology, is the term used to refer to the "study of proper names of all kinds and the origins of names. Anthroponomastics, in turn, is devoted to the study of personal names, under which are subcategories that analyze "given names, surnames, clan names, matronyms, patronyms, teknonyms, nicknames, ethnonyms, autonyms/endonyms, and exonyms", while toponomy or toponomastics focus on place names (Topolovec 4).

Names are integral in literary texts because it is in these that we find the coalescence of reality and fiction. The role of the author as name-giver makes possible the distinctions and affinities between the reality readers inhabit and the milieu of the text. Aristotle, in the Poetics, already mentioned the disparity between the creation of a name and the application of this. However, the systematic study of proper names as used in literary texts began only with the establishment of onomastics as a field of study at the end of the turn of the $19^{\text {th }}$ and $20^{\text {th }}$ centuries (Toth 2).

Onomastics, then, is a critical method of studying the creation of literary universes, whose settings may stand for the real or for an absolute fantasy (Butler 11). The formulation of names for use in this literary world could be seen as a skillful handling of semantic components, and names, together with other literary elements, fulfil a symbolic role that needs to be contextualized within the ambit of the work itself (18).

Allen refers to Alvarez-Altman's definition of literary onomastics as a "field of study in which scholars examine the meaning of names given to characters, peoples, places, and events and then determine how these names relate to the piece of literature's plot, theme, or structure" (72). What we identify as literary onomastics is distinguished from traditional onomastics as the former analyzes an aesthetic artifact and thus underscores "the 
artistic functions of language more than its forms" (Smith in Butler 21), but literature has not really been seen as a field that lends itself to onomastics because it has been deemed lacking in the determinations that will address the linguistic attributes of names (Butler 21-22). Literary names should, in fact, be emulated as representations of referential detail that can be elicited through their usage. Baruch Hochman states that

fictional characters are both configured by and the text and generated in the minds of readers who interpret them in terms of real-life models, so that they both take root in and transcend the text' and it is through a similar heuristic process that names may also come to possess semantic value, shaped by interpretation built around identifiable archetypal patterns . (in Butler 22)

One specific focus of literary onomastics is the utilization of names that have been conceived for literary usage and that have seeped into the wider lexicon, reminding us that literary works are "purposefully fabricated entities", what Gwyneth Jones calls "pieces of equipment" (18). That literary elements carry particular denotations points to the referential power that enables them to symbolize the features that identify these characteristics. These are "pieces of equipment, or literary tools" because these literary elements such as setting or character take on the potency of the narrative affinities to which they are designated, a process that invests names "with a focused sense of identifiable meaning" (18). The act of naming engenders terms that "[draw] their semantic meaning from the referential capacity that a name may hold, [induce] their use as connotational symbolic representations", and in this sense, function in what Lazslo Halász calls "information network[s]", constructed through the symbolic correlations with theme or style that define literary works (18).

In literary onomastics, the meanings, sounds, and forms of names are interpreted within the limits of the text in which these are deployed, and these function as aesthetic artifacts in conju nction with the indispensable necessities of character creation and the production of textual meaning (Robinson 130). Butler supports this by saying that literary components such as setting function as "a guide to the interpretative emotional senses with which the narrative is to be engaged" and elements such as these form the basis of the contextual significance in which symbolic features are applied. This contextual relevance is the foundation in the evaluation of literary components that make for the creation of literary works (24). Names within a text, therefore, take on specific functions within archetypal semantic and symbolic configurations, and are not just "mere background [...] designed to create an atmosphere [alone]" (Nicolaisen qtd. in Butler 24). Names as onomastic tokens bear significant symbolic roles in a literary work, and nominal inventions are a form of "wordsmithing", which is a term applicable too to "onomastic shaping and literary crafting" by which narratives are defined. Each onomastic 
token possesses a meaningful symbolic role within a work, and lexical objects that signify areas, persons, or things, albeit in forms that are nonexistent except in the text, are tenable onomastic entities that provide definitions for nominal functions and the space they occupy in the linguistic landscape (Butler 23). Stjepan Topolovec cites Stanley Lieberson's view that the process of naming involves more components that mark our comprehension of names, such as the application of exceptionally strict rules and standards in creating these name choices (6). Weiss raised the point "that the signification of names varies from the purely nonsensical to the most assuredly allegorical", and that one danger of this was what he termed a "'humptydumptification' of names, an irrational insistence on their fully determinate meaningfulness" (102). This referred to what Peter Alexander noted as Humpty Dumpty's reversal of agreed upon ordering of name meanings, where "in the realm beyond the looking glass, ordinary words mean whatever Humpty Dumpty wishes them to mean, while proper names are presumed to have general significance”. In ordinary life, names are more disputable, conditional, and situational, and we are called to maintain an attitude that looks at nominal connotations as more fluid, while being mindful of the bounds of denotation (103; emphasis added).

Fantasy literature as a genre is remotest from realistic writing, and its attribute and its cardinal measure is "the creation of a world in which causality is based on principles that are, in comparison with the real, everyday world, non-rational (although there may be an internal rationality to the causality of that "secondary" world which is distinct from that of the "real" world)" (Burelbach 131). This "secondary world" is distinguished from the imaginary world engendered by "main line fiction" in that these imaginary worlds are invested with characters and events that, while established on normal, logical rules of causality, are fictive, and did not, and have not really happened, but which could transpire without disturbing familiarly-held epistemologies (132). Referential linkages permeate real world spaces and entities and the validation of the semantic denotation of which in the text are upheld through the contextual characteristics and the genre of the text. This is especially so in the fantastic, which creates absolutely fictional universes and alternate terrains, more than in other literary genres, in which realities pertained to are highly meaningful in plot development (Chanady in Butler 24). We note one perspective of naming that elucidates how literary or mythical entities can be identified, although these live solely in the imagination--- the view that "names are essentially sorts of disguised descrip tions, which necessarily havea sense, but may only coincidentally have a referent, if by chance something in the world corresponds to the description" (Weiss 102). 


\section{The Creation of Worlds: TALA}

In Samar's fantasy series, we really are dealing with two secondary, alternate worlds, one an articulation of the other. The first invented world is one to which we are initially introduced, the world of TALA, the videogame. TALA is the acronym for Terra Anima Legion of Anitos (Samar Tiyanak 2), the game which launches Janus Silang into the mystery and chaos that will drastically alter his circumstances, and indeed, his identity, and literally impel him into other worlds.

TALA appears to be a well-chosen "brand" for an invented Philippine cybergame, because its appeal lies in the fact that it is a well-crafted "strategy game", with the "computer-generated Legion of the Soulless with its diverse creatures of the dark from [Philippine] myths, folktales, and even from urban legends, and these creatures each have their own tactics to stop you from completing a level" $(2-3)^{1}$. The second draw of the game lies in the ingeniousness of the game process. This entails the triumph of a singular player in finding Tala, the "Bathaluman ng Liwanag" or the goddess-muse of Light, and to achieve this, each TALA player needs to create a virtual tandem called BAT (Bayani-Anito Tandem), which is the pairing of a hero and an ancestor spirit, shadow guides who help the player find Tala (3).

This BAT pairing is one significant enticement of TALA as a strategy game because the Bayani (hero) and the Anito (ancestor spirit) are designed as symbiotic entities, and this pairing is unique to each player, and in playing the game's levels, BATs are as sentient as the players in that they sto re knowledge of each level distinct from the player's own, making the repetition of levels a learning experience each time these are embarked into: "The BAT recognizes objects and details that may have been forgotten or may not have been noticed by the player" (3).

Even in the naming of TALA as a contemporary commodified entertainment, names drawn from Philippine mythology have animated the fantasy world of this role-playing game. Its quaintness, has become, in a sense, part of the selling point of the game's narrative for a young Filipino audience that the fantasy novel's plot identifies. We expressly used the term "quaintness" here, because, on a very superficial level, the naming of the game is designed by developers to utilize language that fashions worlds that are fairly realistic, but which still absorbs the players. The Janus Silang series showcases the virtual appeal of manufactured computer games, the reality of which, in much the same way as cybergames, seeps into the fabric of everyday life — in this case, in the life that Janus lives, first in his provincial hometown in Bataan, and then later in a town near Manila as he and 
his allies search for the real Tala and attempt to vanquish the real Tiyanak. This significant and potent connection between the process of name-giving and the society, as well as the comprehension of these names result in new word formations and sound symbolisms that superior fantasy video games employ (Topolovec 16).

The intricacies and multi-dimensional forms of fantasy games are based on nuanced but adept techniques of meticulously created networks of name giving and sound symbolism (16). Videogames are made socially germane by replicating the notable standards, mores, and conventions of contemporary society, and the names games use are crafted to be straightforward in their provision of information, and depictions and references applied contribute to a "well-crafted onomasticon that is reflective of the prevailing social concerns..." (Butler Psychosocial 218). In the novels, TALA initially mines these considerations in the packaging of the videogame, but as the novel unfolds, these merchantable considerations pale in the light of the more mystical operations of Philippine mythology and world-creation as these intimately impact Janus Silang's life, and for which, we shall later learn, TALA the game was created in the first place.

In developing TALA's onomasticon, Samar's Janus Silang is heavily and significantly indebted to the creatures of Philippine lower mythology, a phrase we are expressly using here, in spite of the contested views of this now rather imprecise term. First, we have to note Jordan Clark's useful historical background into the emergence of "lower mythology" to categorize mythical beings. Clark cites the work embarked on by German scholars F.L.W. Schwartz and W. Mannhardt in the $19^{\text {th }}$ century on lower mythology as they began the work of structuring the early myths of Indo-Germanic tribes on which studies about Indo-European mythologies focused. In these works, the term "lower mythology" was a category employed to organize truly complicated mythic structures (https://www.aswangproject.com/lower-mythology/). Lower mythology entities referred to creatures which had no verifiable existence, but whose existence is sustained within folk traditions. These are construed as "demonological", usually seen to instigate maleficence, and are categorized "below spirits, angels, deities, and ghosts", inhabiting water, trees, rocks, or are even disguised as humans.

In the Philippines, the term "lower mythology" as a way to refer to creatures who are not gods, in much the same way as early European classifications made these distinct cataloguing of "high" and "low" entities, was underscored by Maximo Ramos and his landmark text, The Creatures of Philippine Lower Mythology, based on his dissertation under Wayland Hand, former President of The American Folklore Society, that provided a deep and extensive documentation of the creatures of Philippine folklore and mythology. While this Ramos study and categorization is an invaluable addition to Philippine scholarship on anthropology and folklore, the divisions that 
"help[ed] separate the ghouls from the gods" are now effaced by advances in the notions of early belief structures (https://www.aswangproject.com/lower-mythology/), and these sharp binaries are not now tenable in view of the more fluid reckoning of the place and functions of these entities in the totality of the mythic hierarchy within cultures. Frank Lynch echoed this in his review of Ramos's book, stating that while Ramos's cataloguing of Philippine lower mythology creatures into "demons, dragons, and dwarfs [...] elves, ghouls, giants [...] merfolk, ogres, and vampires [...] and viscera suckers, werewolves, and witches", in addition to identifying their traits and functions as being indeed anthropological contributions, "European categories are not always cleanly represented in the Philippines" and that "European preconceptions [...] force Philippine creatures into categories they really do not fit in" (348).

\section{The Naming of Creatures in the Janus Silang series}

A significant wellspring of the foray into new worlds in TALA the game is the population of this world and, by extension, the naming of these inhabitants drawing from Philippine mythos. There are initially eight levels in the videogame - in fact, there will be a new level nine in subsequent Janus Silang books - and not only are these designed for the player to reach Tala, the Paraluman (or goddess-muse), but to confront and vanquish the Tiyanak, which will prove to be Janus Silang's nemesis in his actual life.

In identifying the TALA levels, Janus states:

At the beginning is the Tiyanak because he created all other dark entities in the subsequent levels. The Manananggal and the Mambabarang are in Level 2. The Bungisngis in Level 3. The Berberoka in Level4. The Sigbin in Level 5. The Dambuhalang Sarangay (The Monstrous Bull) in Level 6. The Fairy of the Seven Lakes in Level 7. The Eight Aswangs in Level 8 [...] (Samar Tiyanak 162).

The Manananggal is classified as an aswang. Aswangs, also called asbang by ancient Tagalogs, are creatures who are usually in human form, living as ordinary, unobtrusive and evasive folk, but who have the ability to transform so that they could hurt others when darkness falls. They victimize peoples by eating their innards, or by sucking their blood and other bodily fluids (Samar Kagila-gilalas 47, my translation, emphasis Samar's). The manananggal is a winged, fanged aswang that is able to divide its body in half at nigh t and when the moon is full, the top half of its body able to fly to the roofs of their victims' houses, while the bottom half 
remains on the ground, usually in banana plantations because the lower limbs look like the trunks of banana trunks (48; my translation). The term manananggal is so literally descriptive, as this comes from the word "tanggal", in this sense, meaning "to detach", which is what this creature's special ability is. The Mambabarang is a person able to use insects to victimize others, by doing rituals and prayers, and then uttering whispers to command insects such as beetles, cockroaches, centipedes, or flying termites to enter the victim's body (58; my translation). The "barang" in the mambabarang's designation is both a verb and a noun — as the latter, it refers to the malignant wisdom inherent in witchcraft, and as a verb form, it is the possession and the ill-use of such knowledge. While the structure of the mambabarang's name is similar to the manananggal's in that the verb and its prefix denote ability and the possession of this ability, the mambabarang is more a practitioner of the dark arts and is not physically monstrous. The manananggal as a shapeshifter certainly is.

The Bungisngis, the Berberoka, the Sigbin, and the Dambuhalang Sarangay are all classified as monsters, marvelous or bizarre animals or animal-like creatures, which usually are savage, predatory, wild, taken as denizens of darkness and bringers of misfortune to people and harbingers of the destruction of the world (27; my translation). Burelbach acknowledges that fantasy literature presents many entities with supernatural powers, the source of which and the names corresponding to these characters are my thologies from the diverse Greek, Roman, Norse, Finn pantheons, in addition to African, Asian, American lore available to writers (138). A notable point, then, in reckoning with these mythic nominals in Samar's Janus Silang is that these largely originate in the Philippine regions. While Topolovec does express the contentious view that name giving capitalizes on preconceived ideas, even stereotypes in the society in which these are rooted, fantasy world developers and creators, such as writers, artists, or, in the case of TALA, game developers, use local cultures, beliefs, and relations, even racial and ethnic meanings bred in these milieus, to inscribe these in names (7). We see how, at certain points in the Janus Silang novels, Samar deploys a faithful depiction of, and retain familiar appellations of mythic creatures as these are known locally, but also inventively devises newly created narratives out of these to serve the development of the series's quest motif, thus, freshly weaving the tales of these supernatural creatures into the fabric of Janus Silang's real and alternate worlds.

"Bungisngis" in Tagalog means "giggles" or the act of giggling, and the monster Bungisngis does precisely this, he is a one-eyed immense creature which giggles constantly. Though greedy and extraordinarily strong, Bungisngis is easily bewildered (Samar Kagila-gilalas 39; my translation), and one way to look at the Bungisngis is as being more mischievous rather than malicious. The Berberoka is so named by Ilocanos in the areas of Abra, Apayao, and Ilocos Norte, a sly "freshwater ogre" that "sucks water from swamps or lakes until a 
school of fish is evident in the surface", which it uses to lure fisherfolk. It uses this same water it sucked to kill its victims by drowning them, thereupon it eats its victims (https://filipiknow.net/top-10-terrifying-philippine-

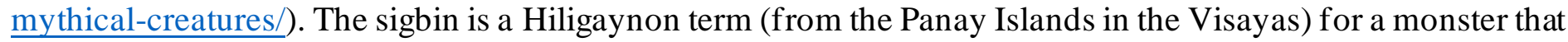
is treated as a pet or a familiar of the aswang. The sigbin frequents the residences of those who are about to die to drink the blood of these victims by sucking at their shadows, hastening their death. Moreover, they steal the bodies of the dead so that they can eat these with their aswang masters. In appearance, the sigbin is a bizarre shapeshifter, and can take on animal forms such as frogs or locusts, or more incredibly, can show itself as a hornless goat, whose front legs are shorter than its hind ones, with flap-like, palm-sized ears, and a long, whiplike tail (Samar Kagila-gilalas 36; my translation). The Sarangay is a bull-like creature "with a huge muscular body and a jewel attached to its ears", which jewel it protects by killing whoever tries to steal it (https://www.definitions.net/definition/Sarangay).

The Diwata, or fairy, in Philippine lore belongs to another class of beings, and is an ancient female goddess (bathala) whose powers are varied and who use these as a boon to save humans, or as punishment for those who offend them, and thus the worship of these beings is determined by what the people need. Diwatas may also be any female protector of nature and the environment (Samar Kagila-gilalas 97; my translation). The etymology of the term "diwata" is "rooted in Hinduism and Buddhism, and the name "diwata" comes from the Hindu term for deity, from "deva", and "devatas", as used in Javanese, Balinese, Sundanese. In Malay and Indonesian cultures, they are "dewata", lesser deities with very specific roles or functions. "Devata" is also the plural of "devas" (the gods), and there are diverse kinds of devas: "vanadevatas (forest spirits, perhaps descendants of early nature-spirit cults), gramadevata (village gods), devata of river crossings, caves, mountains, and others, and, akin to Samar's point, "every human activity has its devata, its spiritual counterpart or aspect" (Clark). The meaning of the "devata" as goddess entities has been watered down to mean "dryad-like spirits", either benevolent or neutral. Jordan Clark notes Jose Rhommel Hernandez's point that in Tagalog, the Indian/Hindu meaning of "Diwata" does not now exist, and Tagalogs deem “diwatas' as fairies. In the Visayas and Mindanao, however, the term has similar signification to the word "anito", meaning ancestor spirit. Some Mindanao groups use the term with the same reference to ancestor spirits, such the T'boli “demwata” (https://www.aswangproject.com/diwata/).

Of all the creatures showcased by Samar in Janus Silang, none is as significant as the Tiyanak. The Tiyanak is not only the archfoe of the TALA videogame, but is, in fact, a real malevolent force and entity that uses Janus Silang to trace a real Tala, in order to vanquish the gods (bathalas) ultimately and completely. The Tiyanak is classified under "lamanlupa", literally meaning creatures that live underground 2 , in ant or termite 
mounds (punso), or in trees such as the balete (ficus or rubber tree). They are not easily seen by humans, because they are elementals in their spirit forms (Samar Kagila-gilalas 9, my translation). In the same guise, very few are able to see them because they are deemed gods whose domain is underground (https://www.pilipinas.bid/2019/09/ano-ang-lamang-lupa.html; my translation).

The "lamanlupa" is a category that loosely translates into "gnomes" contemporarily (cf. https://en.glosbe.com/tl/en/lamanlupa), using a European/Western comparison as the standard for this. Even in the landmark Philippine Folk Literature, Damiana Eugenio indicated tiyanak stories as belonging to the dwarf folk motifs (341), following too folk motif classifications, "elements in a tale that distinguishes it from other tales," which can refer to "an unusual creature, a strange land or a significantly striking or amusing occurrence, i.e., any of the parts into which a tale can be analyzed" which was developed by Stith Thompson, whose exhaustive study of motifs, the Motif-Index of Folk Literature, has been an invaluable toolfor folklorists (Kuehnel and Lencek). This is not quite an accurate translation, as these entities are better termed as elementals, because while they are mostly small, as gnomes are, there are beings among them that are huge and massive (Samar Kagila-gilalas 9; my translation). Moreover, in the Philippine pantheon, these do not just refer to what gnomes and dwarves are in European mythology but take on many varied forms.

The tiyanak is an elemental, "a small but malevolent monster that takes the form of a baby or a young child" that "lures its victim into a forest by crying like a baby. The victim follows the baby's cries and is led deeper and deeper into the forest until he is lost" (Cruz). Tiyanaks are believed to live underground where treasures are buried, and they emerge aboveground at high noon, or at dusk. It usually contrives to be found by childless couples, who the tiyanak will later kill by sucking their blood. While the tiyanak can shift into different forms, and even make itself invisible to deceive its victims (Samar Kagila-gilalas 10-11, my translation), taking on the guise of a baby is what it is best known for because the "general belief is that [it is] the spirit of a ny baby that dies before it is baptized [...] tianacs [sic] always ramble in lonely places, and they usually mislead young folks [...] any one may be safe from being led astray by the tianacs if he would wear his dress inside out" (Eugenio $341)$.

The word "tiyanak" (or, in earlier orthographic versions, "tianac" or "tianak") is thought to be derived from the Tagalog words "patay anak", which means "dead child”. In certain parts of the southern Tagalog regions, such as Batangas, the longer word "patiyanac" or "patianac" is used (https://www.batangashistory.date/2018/11/tiyanak.html), and this more clearly shows this derivation. This again 
illustrates how the tiyanak is seen to be the soul of an unchristened dead infant (Samar Kagila-gilalas 10). In Mindanao, the Mandaya ethnic group use the name "patianak" or "patyanak", and the Bagobo tribe call this the "muntianak" (Samar Kagila-gilalas 11; my translation).

In Janus Silang, the myth of the Tiyanak is inscribed within the primordial narrative of the first humans of Tabon Cave in Palawan. In the course of revealing to Janus the key to the mysterious deaths of those who played TALA the videogame, his newfound companions Renzo and Manong Joey tell him that the Tiyanak was born of the unknown woman of Tabon in truly tumultuous circumstances. The woman carried a child but the paternity of this offspring was in doubt as two men each wanted to claim this child as his own. At the moment of her childbirth, one of these early Tabon men smote his rival with a rock. The woman stabbed the killer, but she was kicked by him, leading her to fall head first into the bonfire in the cave where she took refuge. In the woman's distress and anger as she lived her final moments, she uttered a curse that willed her yet-unborn child to kill the man who slew her (Samar Tiyanak 118).

This child was delivered of its mother, and it was black as if with blood, which made the man who killed its mother think it was dead, only to see that "... its eyes were wide open, it stood up as if it were a child that has long learned to walk...", and in a trice, that same "newborn" reached into the wound where the man was earlier stabbed by the child's mother, and in a trice grabbed his intestines and ate this (119). Janus is horrified by this tale, but more horrifying still is that this was not the first tiyanak, "it was the only Tiyanak [...] born in the caves of Tabon thousands of years ago, and who, is the self-same Tiyanak they all have seen [...] It has changed appearances, pretending to be different children, but who is all of those" (120).

The horror of the Tiyanak's transformation is amplified when Janus realizes the extent of the Tiyanak's malice, and how this malice is so directly trained at him and his family, as the younger sister he thought he has, Juno, is really the Tiyanak. The sister he doted on was actually a young girl whom only he could see, as the Tiyanak has so manipulated his and his parents' minds, in order to access Janus's hidden knowledge of where Tala could be. The Tiyanak has long suspected that Janus is a Pusong even before Janus realized it, and it insidiously inserted itself into Janus's family for years to surveil all Janus may know. Juno was an evil trick he played on Janus. In the end, Janus loses all he loved — Juno was a malignant illusion, his father was, in fact, long dead and was replaced by a Dool, a shapeshifting creature the Tiyanak created, and worst of all, his mother was killed by the Tiyanak, which later even ate Janus's mother's viscera as an act of cruel abomination. 


\section{Creation of Worlds: Kalibutan}

Janus Silang's inscription into an alternate world appears activated by the Tiyanak's malevolent plans, but is, in fact, an immersion in a more immense design, and the presentation of this Philippine conception of its mythological cosmos is a distinctive contribution of the Janus Silang series into the narratology of fantastic worlds. John Algeo avers the power of writers of fantasy works as "creators of a world whose boundaries are only what the authors choose", and as "name givers" who are able to apply that freedom to characters, places, objects, events in a manner that makes these apt and uncontrived, making fantasy "therefore potentially the richest of all genres of literature for onomastic analysis focusing on a connection between the name and the named" (252). Kara Kennedy echoes Algeo's point, stating that characters, places, and events that create a "three-dimensional, immersive world" is constitutive of the worldbuilding process in the fantasy and science fiction genres, and the significance of naming needs to be thoroughly studied in the engendering of fantastical and distinct secondary worlds with which readers can be enthralled but which they can also totally accept(99). In JanusSilang, however, the worldbuilding does not primarily rely on the invention of an unknown world, or on the devising of new words, but in the reintroduction of Philippine myths and lore elements and vivifying these by interweaving these within the contemporary adventures of Janus Silang as protagonist in this Philippine fantasy text as these mythical creatures and tales are familiarly known, or as articulated narratives born of these local lore, that now imaginatively expand on, and reimagine, Janus Silang's alternate universe.

The world of Janus that corresponds to recognizable Philippine contemporary life - the reference to recognizable and familiar places, such as Balanga in Bataan where Janus and his family live, or Angono where Manong Joey's residence and headquarters are, Marikina where Renzo stays with his Aunt Cely, or landmarks such as fastfood places like McDonalds, but these current realities are also overlaid with invented contemporary inventions peculiar to Janus's other life, such as the underground train system known only to, and which are only for, baganis, which network is existent all over the Philippines, called "trip" — a contraction of "Treng Dyip" [train that is also a jeepney] and these secret transportations do have real, familiar referents in the train and the jeepney (Samar Pusong 16-17). We had earlier noted TALA, the videogame, as another of these artifactual onomastic inventions that the series so inventively utilizes to summon us into an alternate world. Even known wars, such as the Second World War, is understood here, not just in the sense of this global battle:

To the bagani, the 40s were not just about the Second World War. They named this the Battle between the Manananggal and the Mambabarang, the triumph of the world against its 
annihilation desired by the Tiyanak, and this was a double victory on the part of the bagani because they were joined in the fight against the Tiyanak by the manananggal, the Tiyanak's firstborn. (150-151)

To make sense of Janus's complicity with a mystical world is to understand his place in that world, the expanse of which is called Kalibutan, whichmeans world. The Visayan "kalibutan"(used in Cebuano/Sugbuanon, Waray, Inakbanon in the Eastern Visayas, for instance) corresponds to the Tagalog "daigdig", or the English "world" (https://corporaproject.org/index.php?word_search=kalibutan\&\&language=24). It is this concept of worlds or realms that is also very evocative, because in the creation story of Kalibutan, it is a world created by nine gods or Bathalas (Samar Labanang 141), the conception of the creation of the world is that the world's foundation is a series of additions and revisions. "Kalibutan" is the "name given to the other half of our world" (149), where places that exist in our reality find their duplicate, as in the other Balanga Esther the manananggal resides in as she watches over Janus in the Balanga in which he lives (cf. 162). Kalibutan is like a "hologram", "a single space..." in which the nuno and the diwatas also exist, but in which realities are projected differently" (90).

The First World of Kalibutan also brought about the End (Hanggahan), or the limit to the Expanse (Kalawakan), this birthed Space and Order, and the nine Bathalas initially deemed that these principles were sufficient for the world to be set in motion. In the course of renewing the world, they dismantled each world in order to add new principles that will maintain this Order. To these changes, they added first, Time, then Life, and by the time they reached an eighth making of the world, they discovered the conflict between Life and the End. And so, they realized that they need to bring about Death in order to revive Order, and in doing so, needed to destroy the eighth world. The nine gods of the universe, in establishing the Ninth World, took responsibility for the making of specific creatures that live and die (94-95).

We note here that the term "Bathala" is taken from the Tagalog indigenous belief in an omnipotent deity who created the universe, whose name can also be spelled as Batala (https://www.definitions.net/definition/Bathala). "Bathala" is deemed to originate from the Sanskrit Bhattara Guru or "the highest of the gods"(https://www.tagaloglang.com/bathala-the-tagalog-god/). Clark cites F. Landa Jocano who stated that "Bathala is the grand conserver of the universe - the caretaker of nature and the creatures of the earth, and from this comes the meaning of "'bahala' or 'mabahala' meaning "to care." From this evolved the Filipino attitude of "bahala na" or "Let Bathala take care of it" which gives a person tremendous courage in the face of danger" (https://www.aswangproject.com/bathala/). In Tagalog, a descriptive honorific is appended to 
the name Bathala, such as "Bathalang Maylicha [Maylikha] (Bathala the Creator; lit. "Actor of Creation")" and as the Bathalang Maycapal [Maykapal] (Bathala the Almighty; lit. "Actor of Power")" (https://www.definitions.net/definition/Bathala).

The creation of Kalibutan in Janus Silang unfolds thus:

The first god created the Nuno (ancestor spirits), who are holders of the memories of ancient worlds, are responsible for originating the opening and the closing of the Ninth World. The second Bathala created the fairy-goddesses, the Diwatas, creatures who will cultivate and care for plants and trees that infuse the world with Color and Beauty. The Baganis were created by the third Bathala, and the bagani is a creature, who by virtue of their strength and power, preserve Order in the world. The fourth Bathala created the Pusong, the creature who is the fount of change, tasked with the care of the emotions and inner wellbeing of other beings. The fifth deity created humans, creatures of innocence, made so that mystery and wonder which is a wellspring of Life could be sustained, and they do this by creating legends and tales. Animals are the creation of the sixth god [...] and the seventh god made Bacteria, creatures that live in animals and men [...] which will be the last to perish before the Nuno closes the world at the end of time. And the eighth Bathala created the Mangindusa, guardians of the world and preservers of Order, bringers of grace and retribution, of plagues and plenty, of rains and heat, of shadow and light, maintaining the rhythm of nature, who provide amplitude to respond to every need. The ninth god created the Hidden Creature, and for this, he is the only deity who has dealings with the creatures of the world, by way of which interactions he is able to keep hidden the secret creature he made. In this new world they created, Death and the Hidden Creature are forces that are needed to ensure the continuity of this world. (Samar Labanang 9597)

It is this ninth god who had relations with the woman, Alindog (meaning charm or allure), in Tabon cave in the guise of a hunter, who fathered the Tiyanak and Tala, the one who has the power to destroy the Ninth World, and the other, the creature who could prevent this and who could slay the Tiyanak (97).

In this world-making, Tiyanaks or aswangs do not figure in the creatures made by the gods, and this is among the Tiyanak's overriding bitterness in its enmity against the gods, that the world had been created before he came into it, and that he was not part of the plan, created by not one of the nine Bathalas and the mistake of 
one of them (141). Part of the retaliation of the Tiyanak is to make his own creatures. In the books of knowledge held by the baganis, the Tiyanak created the Manananggal, which mocked the human desire for flight, but unlike the malice the Tiyanak expected would be preeminent in his creature, the Manananggal in Janus Silang became a being who learned how to love humans, and who lived a separate existence from the Tiyanak that created it (146-147). This revises the depiction of the Manananggal as simply bizarre monsters which desire human flesh, and invests them with sentience and complex emotions. Another tale-reworking in this fantasy series is the mention of Malakas and Maganda (The Strong One and the Beautiful One), not as the first creatures who emerged from a split bamboo stem in Philippine my thology, but as the first followers of the Tiyanak (143). Indeed, Malakas and Maganda are the first two creatures of the Tiyanak - the first Manananggal and the first Mambabarang made from mud that it packed into bamboo, into which it breathed the horror of life. Malakas needed strength in order to endure his monstrous transformation, and Maganda, as the first Mambabarang, possessed allure and glamor to beguile her victims and show them only the most attractive things at the moment of her most terrifying deception (192-193).

More significantly, this creation myth of the nine Bathalas presents to us the presence, and the hierarchy of, beings. We pay particular attention here to the Bagani and the Pusong, which are paramount ranks that move this narrative along. The word "Bagani" is so potent in Philippine culture because among its well-known derivatives is the Tagalog nominal "bayani" (meaning hero), or the Kapampangan adjective "bayani” (meaning brave or strong). Perhaps lesser-recognized is the Aklanon noun "bagani(h)", which also means hero (Ching). "Bagani" as a term can be tracked back to its Proto-Malayo-Polynesian roots, "barani," meaning "hero or warleader," but also signifies “[to] dare to do". The term "bagani”, however, denotes more than just a blanket word for bravery or heroism, and this, instead, is deemed by several indigenous groups in Southern Philippines to refer to a complex and specific cultural concept: “The bagani of Mindanao's indigenous peoples is not just courageous or charismatic in the same way that the bayani of the Filipino is; he is a definitive part of their community's structure and is not merely an abstract figure in the annals of indigenous peoples' history" (Ching). The Mandayas of the Davao region deem the "bagani" as a warrior class within their social hierarchy, a warrior chief; the Manobos look to him as a "warrior priest" who is favored by the gods and given "strength and skill in battle" that enables him to kill, and, conversely, the power to heal (Ching). In Janus Silang, baganis like Manong Joey and Manong Isyo, who possess long lives and psychic powers, or Ma'am Ludinia, whose bagani clan is able to draw power from the natural world (Samar Labanang 17), or ancient bagani families like the Esturas, the Andreses, the Guerreros, the Gracios are "in a race against the Tiyanak to find Tala” (Samar Tiyanak 137). 
And the key to finding Tala, the Tiyanak's twin and the only one who can kill it, is by way of the Pusongs, of which Janus is one, as his own father was. The word "pusong" in Tagalog means "buffoonery" or "foolishness", and the person of the pusong is "foolish, impudent, profane" (https://www.wordsense.eu/pusong/). In Janus Silang, the pusong is not portrayed in this manner, but their trickery may lie in the power they have to jump back into time (Samar Pusong 118), and their ability to take on animal forms, and all their liminal and ludic powers as pusongs are in the service of finding Tala. This artfulness and shrewdness are seen in the first Pusong who saved the infant Tala, Pilandok, who is able to hide Tala from the Tiyanak and from the first Bagani who was deceived by the Tiyanak. "Pilandok", which literally refers to the mouse deer (https://www.tagaloglang.com/pilandok/), the animal into which he transforms, is characterized by this fleetness and quick-thinking in the face of danger. It is worth noting that Janus's ancestor Mahang, who first compiled the knowledge of and about pusongs, took on the name "Siláng" - Mahang of Siláng (138) - in which "Siláng" is a toponym, a place name that refers to "a trace of a path in the mountains or on the plains", an apt appellation because they come from a line of pusongs "who have rendered these ways passable, those who created all human pathways" (138). This anthroponym is revelatory of Janus's lineage as it is of his mystical role, but it also calls to another meaning of "Silang", "to be born".

This naming is also significant especially when we take into account Janus's first name, which is unexpectedly Western. Janus is a Roman Numina, "protectors of sowers and the seed", "the god of good beginnings" (Hamilton 45). In Roman mythology, he is "the god of beginnings and transitions", who presided over passages, doors, gates and endings, as well as in transitional periods such as from war to peace”, an d is best known in his depiction "as having two faces looking at opposite ways, one towards the past and the other towards the future" (https://www.greekmythology.com/Myths/Roman/Janus/janus.html). As the "god of gates and doors", Janus "held the key [...] to the metaphorical doors and gateways between what was and what is to come-the liminal space of transitioning out of one period of time and into something new" (https://www.andersonlock.com/blog/god-doors/). Janus Silang's naming so aptly captures his ability to belong to both his world and Kalibutan, his ability to stay in the present and also to travel to the past, his p owers to outwit the Tiyanak, and all allude to what the Paraluman says about the Pusong they are waiting for: "that the one who will point the way to the Root will come from the Fruit that grows in another Time" (Samar Pusong 111-112).

\section{Conclusion}


In reckoning with many categories of naming in Samar's Janus Silang series, we have shown how this contemporary Philippine fantasy work has successfully presented an onomasticon of Philippine mythological creatures and secondary worlds that inventively introduced "new objects, artifacts, technologies, customs, institutions, ideas" and conceived "imagined cultures [...] modeled after real cultures, using different combinations of their traits that an audience might find familiar, but in new configurations"(Kennedy 100). Janus Silang has achieved this by way of presenting recognizable contemporary Filipino worlds and everyday lives as embodied either in known or unfamiliar ways, represented by Filipino names and referents. The naming of worlds, their creatures, and the narratives and processes of their creation, reactivates the remembrance of Philippine myths and lore, either as faithfully rendered or as revised, and invented reintroductions to these imaginary worlds.

Finally, we have to note that the use of Filipino as the language of the novel series contributed not just a "quaint charm" to this fantasy narrative by mining the exoticization of creating "Filipinized" fantasy worlds. We assert the integral indispensability of this language's use here as it anchors these fantastic worlds and realities that are both ancient and novel, familiar and strange, in the Filipino readers' own informational, cultural, psychical, and metaphysical terrains. Filipino beliefs in mythical creatures, and how they co-exist in the context of local life, are not just employed in Janus Silang to create familiar supernatural backgrounds that draw readers to it by virtue of this very familiarity, which is the surface appeal of many other fantasy novels. What the novels succeed in doing is melding these local mythical elements to serve a new narrative of alternate Filipino worlds. This has allowed us to examine the naming of beings, entities, places, objects in these novels not only in terms of the referential, but also by way of the symbolic values of these nominals. Samar was able to "produce change s in the nominal and cultural realms that gesture towards an even larger, more expansive, universe than is described in the story", and his "world-building [...] successfully set[s] up the illusion of completeness and allow[s] readers' pre-existing knowledge to fill in the gaps" (100). The success and signal contribution of Samar's Janus Silang series is in the unfolding of an intricately detailed Kalibutan and Santinakpan by suturing together a grand narrative of good and evil that brings in diverse aspects of Filipino supernatural lore. In this paper, we have largely underscored the power of naming that manifested a uniquely Filipjno mythic world by focusing mainly on how the novels maneuvered around these named fantastic elements from Philippine lore seen in everyday life and in virtual reality, in mundane existence vis-à-vis mythic worlds. There are, too, in Samar's fantasy series, other instances of naming other speculative aspects in Filipino that are totally novel and which do not simply replicate known myths and creatures, but which are instead onomastic rhizomes that begin to play with these by providing these known nominal assignments new fictional twists to flesh out Samar's vision of this alternate Filipino world, 
which is still unfolding as the series has not yet finished. In addition to these, Samar builds on other aspects of lived experience, such as personal appellations and titles, invented transport systems and cyber applications, which can be examined further in future studies of this series. All these bode well for fantasy fiction in the Philippines, as we see how the awareness of naming becomes a potent literary tactic in crafting future speculative writing in Philippine literature. In Janus Silang, we noted the use of familiar Filipino mythic elements, but this naming opens even more portals to the imaginative crafting of original creatures and elements born of the author's ideation not only of Filipino mythos, but perhaps of other cultures as well, or even of totally new, hitherto unknown, conceptions of worlds and universes.

\section{Notes}

1. All quotes from the Janus Silang books are originally written in Filipino and all English translations are mine.

2. The term used for "lamanlupa" in Pangasinan is "kaibaan" (see Samar Sinaunang 9), which may come from the root word "íba", meaning "companion; to accompany (-an); to help (man-)", or from the term "kaíba" which means accompaniment (Benton 46). The contemporary translation of "Akaibaan", is to be "made fun of by the "ancestor in the anthill" (Ogalesco https://www.aswangproject.com/nuno-sa-punso/) ["napagkatuwaan ng mga nuno sa punso" - in Tagalog] (Alambra). This gives another meaning to "lamanlupa" as companions from another world who either help humans or make mischief and harm them.

\section{Works Cited}

“10 Lesser-Known Mythical Creatures in Philippine Folklore.” FilipiKnow, 9 March 2019.

https://filipiknow.net/top-10-terrif ying-philippine-mythical-creatures/ Accessed 16 March 2021.

“A 1922 “Tiyanak” Story set at the foot of Mount Makulot in Cuenca, Batangas.” Batangas

History, Culture \& Folklore, 3 November 2018,

https://www.batangashistory.date/2018/11/tiyanak.html. Accessed 18 March 2021. 
“ABS-CBN obtains TV rights to 'Janus Silang' series.” ABS-CBN News. 3 September 2018, https://news.abs-cbn.com/life/09/03/18/abs-cbn-obtains-tv-rights-to-janus-silang-series Accessed 23 March 2021.

Alambra, Aurora Verceles. "Diabetes scare in the family; akaibaan, kayu-kayo, bari-bari!"

The Sunstar Baguio, 21 November 2019,

https://www.sunstar.com.ph/article/1833043/Baguio/Opinion/Alambra-Diabetes-scare-in-thefamily-akaibaan-kayu-kayo-bari-bari! Accessed 14 March 2021.

Algeo, John. "A Fancy for the Fantastic: Reflections on Names in Fantasy

Literature." Names: A Journal of Onomastics, vol. 49, no.4, 248-253, (2001) DOI: 10.1179/nam.2001.49.4.248. Accessed 8 April 2020.

Allen, Spencer L. “A Rebel by Any Other Name: The Onomastics of Disney’s Star Wars

Rebels." The Journal of Religion and Popular Culture vol. 31, no.1, Spring 2019, doi:10.3138/jrpc.2017-0020. Accessed 8 April 2020.

“Ano ang lamang-lupa?” https://www.pilipinas.bid/2019/09/ano-ang-lamang-lupa.html

Accessed 16 March 2021.

"Bathala, the Tagalog God" n.d. https://www.tagaloglang.com/bathala-the-tagalog-god/ Accessed 17 March 2021.

Benton, Richard A. “I.” Pangasinan Dictionary, University of Hawai'i Press, Honolulu, 1971, pp. 46-49. JSTOR, www.jstor.org/stable/j.ctv9hvsfz.12. Accessed 16 Mar. 2021.

Bright, William. "What Is A Name? Reflections on Onomastics." Language and Linguistics, vol. 4, no. 4, 2003, pp. 669-81.

https://www.researchgate.net/publication/253085133_What_IS_a_Name_Reflections_on_Onomasti cs. Accessed 8 April 2020. 
Burelbach, Frederick M. “An Introduction to Naming in the Literature of Fantasy." Literary

Onomastics Studies, vol. 9, Article 11, 1982,

http://digitalcommons.brockport.edu/los/vo19/iss1/11. Accessed 8 April 2020.

Butler, James Odelle. Name, place, and emotional space: Themed Semantics in Literary

Onomastic Research.2013. University of Glasgow, Ph.D. dissertation.

http://theses.gla.ac.uk/4165/ Accessed 8 April 2020.

Butler, James O. "The Psychosocial Ramifications of Videogame Naming and Representation in the Early Years of The Simpsons.” Names: A Journal of Onomastics, vol. 63, no.4, 2015, pp. 210-19,

https://www.tandfonline.com/ DOI:10.1080/00277738.2015.1118985. 8 April 2020.

Cayabyab, Marc Jayson. "Philippine folklore meets technology in 'Janus Silang' play

adaptation.” Inquirer.net. 5 February 2017, https://lifestyle.inquirer.net/253558/philippine-folklore-meetstechnology-janus-silang-play-adaptation/ Accessed 23 March 2021.

Ching, Marrian Pio Roda. “Is ‘Bagani’ culturally appropriating indigenous peoples?” CNN

Philippines. 26 March 2018. https://cnnphilippines.com/life/culture/2018/03/26/bagani-cultural-appropriationindigenous-people.html Accessed 26 March 2021.

Clark, Jordan. "The Diwata Of Philippine Mythology: Forest Spirits \& Goddesses.” The Aswang

Project. 3 March 2016, https://www.aswangproject.com/diwata/ Accessed 16 March 2021.

---. "The Problem and the Importance of "Lower Mythology” in Philippine Folklore." The

Aswang Project, 3 June 2015, https://www.aswangproject.com/lower-mythology/

Accessed 19 March 2021.

---. “The Tagalogs Origin Myths: Bathala The Creator.” The Aswang Project, 13 February 2016, https://www.aswangproject.com/bathala/ Accessed 18 March 2021.

Cruz, Neal H. "Philippine mythological monsters for Halloween.” Philippine Daily Inquirer, 31 
October 2011, https://opinion.inquirer.net/16299/philippine-mythological-monsters-forhalloween\#ixzz6pzU03L48 Accessed 18 March 2021.

De Vera, Ruel S. “Modernizing a Mythical Monster.” Philippine Daily Inquirer, 4 May 2014. https://lifestyle.inquirer.net/158736/modernizing-a-mythical-monster/\#ixzz6qKCLYhTR Accessed 23 March 2021.

Eugenio, Damiana. Philippine Folk Literature: The Legends. U of the Philippines P, 2005.

Hamilton, Edith. Mythology: Timeless Tales of Gods and Heroes. Meridian. 1989.

“Janus.” Greek Mythology. n.d.

https://www.greekmythology.com/Myths/Roman/Janus/janus.html Accessed 23 March 2021.

"Kalibutan" n.d. 3NSCorpora Project.

https://corporaproject.org/index.php?word_search=kalibutan\&\&language=24. Accessed 14 June 2021.

Kennedy, Kara. "Epic World-Building: Names and Cultures in Dune." Names: A Journal of

Onomastics, vol. 64, no.2, 2016, pp. 99-108. https://www.tandfonline.com/ DOI:

10.1080/00277738.2016.1159450. Accessed 8 April 2020.

Kuehnel, Richard and Rado Lencek. "What is a Folklore Motif?" n.d.

https://www.aktuellum.com/mobile/slavic/folklore-motif/ Accessed 12 March 2021.

“Lamanlupa." n.d. https://en.glosbe.com/tt/en/lamanlupa Accessed 16 March 2021.

Lynch, Frank. Review of Creatures of Philippine Lower Mythology by Maximo Ramos.

Philippine Studies vol. 20, no. 2, 1972, 348. PDF. Accessed 23 March 2021.

Ogalesco, John Patrick. "Nuno sa Punso: The Mound Dweller.” The Aswang Project, 12 November 2016, https://www.aswangproject.com/nuno-sa-punso/ Accessed 18 March 2021. 
"Pilandok." n.d. https://www.tagaloglang.com/pilandok/ Accessed 17 March 2021.

"Pusong." n.d. WordSense Online Dictionary. https://www.wordsense.eu/pusong/. Accessed 14th June, 2021.

Robinson, Christopher L. "Onomaturgy vs. Onomastics: An Introduction to the Namecraft of Ursula K. Le Guin.” Names: A Journal of Onomastics, vol. 59, no. 3, 2011, pp. 129-38, DOI:10.1179/002777311X12976826704208. Accessed 8 April 2020.

Samar, Edgar C. 101 Kagila-gilalas na Nilalang. Adarna House, 2015.

---. Si Janus Silang at ang Labanang Manananggal-Mambabarang. Adarna House, 2015.

---. Si Janus Silang at ang Pitumpu't Pitong Pusong. Adarna House, 2017.

---. Si Janus Silang at ang Tiyanakng Tabon. Adarna House, 2014.

“Sarangay.” n.d. https://www.definitions.net/definition/Sarangay Accessed 17 March 2021.

"The God of Doors, Gates, and Transitions: History of the Ancient Roman God Janus." n.d. https://www.andersonlock.com/blog/god-doors/ Accessed 21 March 2021.

Topolovec, Stjepan. The Cultural and Linguistic Aspects of Naming in Fantasy Video Games. 2012. University of Osijek, Ph.D. Dissertation. PDF. Accessed 8 April 2020.

Tóth, László. Theory and methodology in literary onomastics: Proper names in István Szilágyi’s novels (in particular in Hollóidő/Time of ravens/). 2014. Pázmány Péter Catholic University, Theses of Ph.D. dissertation. PDF. Accessed 8 April 2020. 


\section{SARE, Vol. 58, Issue $1 \mid 2021$}

Weiss, Allen S. "Imaginary Onomastics" Translation Studies, vol. 12, no.1, 2019, pp. 100-108, DOI: 10.1080/14781700.2019.1669486. Accessed 8 April 2020. 